УДК 94(477)

СЕРЕДЮК М.С.

https://orcid.org/0000-0003-4539-5782

https://doi.org/10.33577/2313-5603.31.2019.42-52

\title{
ВОЛОДИМИР ЦЕЛЕВИЧ: ВНЕСОК У ЗАСНУВАННЯ УКРАЇНСЬКОГО ГОРОЖАНСЬКОГО КОМІТЕТУ ТА УКРАЇНСЬКОЇ ВІЙСЬКОВОЇ ОРГАНІ ЗАЦЇ̈
}

Проаналізовано громадсько-політичну діяльність відомого галицького політика Володимира Целевича у перші два десятиліття XX ст. крізь призму суспільно-політичних процесів у регіоні. Акцентовано увагу на особливостях формування його світогляду, внеску у заснування Українського Горожанського Комітету (УГК), Української військової організації (УВО), виокремлено коло його однодумців, серед яких - майбутні лідери національно-державницьких партій Галичини, національно-культурних організацій краю. Відзначено, що, перебуваючи в УГК, УВО у період національно-визвольних змагань, польськоукраїнської війни 1918 - 1919 рр., він доклав чимало зусиль для захисту національно-культурних, соціально-політичних прав українців Східної Галичини, через що зазнав репресій та переслідувань від польської влади.

Ключові слова: В. Целевич, ЗУНР, Український Горожанський Комітет, Українська військова організація, польсько-українська війна, репресії.

У роки Першої світової війни, польсько-української війни 1918 - 1919 рр. на «політичній арені» Східної Галичини з’явилась постать Володимира Целевича - одного з найавторитетніших українських політиків першої половини XX ст. У синтезі історії України, у спеціальних працях, які присвячених історії створення Українського Горожанського Комітету (УГК), Української військової організації (УВО), належним чином не відображена його громадськополітична праця у цих організаціях. Важливі зрізи його біографії здебільшого розкриваються у публікаціях історико-біографічного, джерелознавчого та іншого тематичного спрямування. Дослідження часто некоректно відображають суспільні реалії та події, учасником яких був один із лідерів націонал-демократів, нав'язують суб'єктивні погляди й оцінки. Окреслені чинники зумовили авторське зацікавлення проблемою.

Володимир Целевич народився у 1890 р. (або ж 1891 р.) у с. Русатичі Бобрецького повіту Львівського воєводства у родині

Середюк Марія Степанівна, здобувач Інституту українознавства ім. І. Крип'якевича НАН України, м. Львів.

(C) Середюк М.С., 2019 
сільського учителя Михайла Целевича (украинские националистические организации в годы Второй мировой войны, 2005: 1085). непересічна ерудиція, потяг до гуманітарних дисциплін дозволили йому після закінчення сільської школи та гімназії вступити на юридичний факультет Львівського університету імені Яна Казимира. Одразу ж «як начитаний і свідомий українець, він зі студентських років поринув у вир суспільно-громадського та культурного життя» (Качкан, 2009: 162).

Спогади його сучасників свідчать, що майбутній лідер УНДО «майже постійно» був членом Виділу IV Секції Українського Студентського Союзу (УСС), а також націонал-демократичної секції цієї студентської організації, де гуртувалися студенти-прихильники Української Національно-Демократичної Партії (УНДП). У цей період головою Секції був В. Пежанський, членами Виділу разом iз В. Целевичем - С. Коновалець та М. Струтинський (Навроцзький, 1963: 53). 3-поміж тогочасних акцій, які провели члени студентської організації, виокремимо оприлюднену УСС відозву «За український університет», яка викликала широкий резонанс у регіоні. Передумови цієї політичної акції описав О. Зінкевич: «Захопившись візією існування українського університету у Львові, як святині української науки і культури, С. Коновалець ініціює підписання спільної деклярації представниками всіх студентських організацій і секцій - «За український університет». Власне серед студентів, які підписали документ, знаходимо прізвище В. Целевича (Свген Коновалець та його доба, 1974: 104). У декларації з обуренням зазначалося: «Заявляємо торжественно, що ми і надальше стоятимемо 3 цілою рішучістю при домаганню цілого народу за заснування самостійного українського університету з осідком у Львові» (Діло, 1913: 1).

У роки Першої світової війни, як зазначав О. Навроцький, «Володимир Целевич був уже «добрим правником і мав політичний нерв та вже деякий досвід у громадському житті» (Навроцький, 1963: 55). Ймовірно, тоді ж він розпочав роботу на посаді судді м. Львова. Ці факти дозволили йому стати одним із засновників, а згодом - секретарем Українського Горожанського Комітету м. Львова (УГК), нав'язати контакти із відомими громадсько-політичними діячами, військовими, серед яких його найближчі товариші М. Матчак та С. Федак.

Так у розпал польсько-української війни 5 грудня 1918 р. Польський Тимчасовий Комітет (ПТК) дозволив С. Федаку заснувати 
УГК із застереженням, що діяльність організації буде спрямовано виключно на «задоволення щоденних потреб і охорони українців Львова» (ЦДІАЛ Украӥни, ф. 462, оn. 1, спр. 2, арк. 1). В одному із перших звернень УГК наголосив, що розпочинає діяльність «у найбільш трагічні хвилини нашого національного і державного життя..., серед нерозумного засліплення і ненависті, серед оргій помсти ображеної величі, серед цілковитого розвалу усіх основ громадського життя...» (ЦДІАЛ України, ф. 462, оn. 1, спр. 3, арк. 24). Згідно зі Статутом найвищим органом УГК проголошувалися загальні збори. Також утворено Малу (займалася поточними справами) та Велику Ради у складі почесних, звичайних членів і добродіїв, яка вирішувала усі «складні» питання діяльності Комітету.

Секретарем УГК обрано В. Целевича (1919 - 1921 рр.). При організації діяла низка комітетів та секцій, які надавали матеріальну допомогу полоненим, інтернованим, арештованим і немічним, самаритянську допомогу, займалися посередництвом у питаннях працевлаштування, давали правові поради (управлінську шкільну), допомагали гірським повітам (ЦДІАЛ України, ф. 462, оn. 1, сnр. 3, арк. 1 зв.). Наголосимо, що виконувати статутні завдання УГК допомагала українська еміграція. Сучасники подій відзначають: «На диво, найменше було клопоту з фондами. Американська, а передусім канадська еміграції виявили себе такими жертвенними, як ніколи перед тим і ніколи пізніше. Напливали гроші поважними сумами, одного разу від Українського Канадського Червоного Хреста прийшов чек на п'ять тисяч долярів, що в тому часі, перерахувавши на польські гроші, було колосальною сумою. Приходили великі посилки 3 харчами, одягом, медикаментами та іншими речами. А що не було їх де примістити, то д-р Федак «зареквірував» для тієї цілі залю «Сокола-Батька». Майже до стелі сягали мішки і скрині...» (Навроиький, 1963: 67).

Отже, можемо зробити висновок, що, по-перше, В. Целевич в умовах воєнних дій 1918 - 1919 рр. отримував необхідні для життя фінансові та матеріальні засоби. По-друге, працюючи секретарем УГК, він нав'язав контакти із українською еміграцією, що дозволило йому на початку 1920-х рр. емігрувати до США та продовжити збір коштів на потреби українського національновизвольного руху у краї.

Особливості створення та діяльності УГК, зокрема іiі секретаря В. Целевича, яскраво ілюструють спогади 3. Книша. Громадськополітичний діяч констатував: «На початку 1919 року д-р Лев Ганкевич і д-р Степан Федак вистаралися в ген. Розвадовського, 
коменданта Львова, про дозвіл заложити Український Горожанський Комітет. Цей Комітет мав різні Секції, як правну, опіки над інтернованими і полоненими, допомоги політичним в'язням і т. д. Особливо повні руки роботи мала Секція Правних Порад у часі, коли поляки, ідучи вслід за українською армією в відступі, арештували українців, що працювали в урядах за своєї влади, позбавляли їх праці і платні та інтернували. В Українському Горожанському Комітеті працювали, крім д-ра Лева Ганкевича і д-ра Степана Федака, проф. Маріян Панчишин, його брат-правник, Ольга Кривокульська (пізніша дружина проф. Маріяна Панчишина), суддя Володимир Целевич, Білобрамівна (пізніша дружина молодшого д-ра Панчишина), а потім ще Ярослав Чиж, Осип Навроцький та інші. Деякі $з$ тих осіб зайняли пізніше високі керівні пости в Українській Військовій Організації» (Книш, 1963: 23).

До УГК В. Целевич запросив також О. Навроцького: «Десь 3 початком вересня я наткнувся на Руській вулиці на Володимира Целевича, мого доброго знайомого і товариша з львівського університету та з Академічного Дому, - згадував той згодом. - Коли по першім привітанні він довідався, що я не знаю, що 3 собою робити, одразу запропонував мені роботу на пості начальника канцелярії в Українськім Горожанськім Комітеті, де він був секретарем. Володимир Целевич договорився зо мною, що другого дня вранці підемо до Голови УГК, д-ра Степана Федака. Д-р Степан Федак знав мене 3-перед війни. Він був головним директором «Дністра» $\mathrm{i}$ «Карпатії, а я працював там як кореспондент. Привітав він мене з поворотом з війни, як знайомого, і без балачок затвердив пропозицію Володимира Целевича. 3 бюра дир. Степана Федака в «Дністрі» ми обидва з Целевичем пішли до канцелярії УГК по другій стороні Руської вулиці під ч. 3, II поверх» (Навроцький, 1963: 72).

Згодом, В. Целевич познайомив О. Навроцького із членом УГК Я. Чижом, який запропонував тому створити «осередоккоманду [УВО - $\boldsymbol{A в m}$.] та намітити до неї ще двох членів, $з$ таким застереженням, щоб нічого [поки що - $\boldsymbol{A в m . ] ~ н е ~ г о в о р и т и ~ п р о ~}$ УВО» (Наврочький, 1963: 72). «Над пропозицією Ярослава Чижа я довго не надумувався, - відзначав О. Навроцький, - і по короткій розмові погодився на неї... Після розмови з Ярославом Чижем вернувся я до канцелярії УГК і, коли побачив Володимира Целевича, з місця рішився запропонувати його на члена Команди, хоч він не був військовиком» (Навроцький, 1963: 73). 
О. Навроцький констатував, що «швидко рішився запропонувати Юрка Полянського на третього члена Команди». Я. Чиж i М. Матчак погодилися на його пропозицію, після чого «він негайно після того розмовився з Володимиром Целевичем і Юрком Полянським. Вони теж погодилися, без ніяких застережень. Внедовзі ми зійшлися всі п'ять, таки в бюрі УГК, і устійнили, що ця нова станиця буде називатися «Начальна Колегія Української Військової Організації» (Навроцький, 1963: 73).

Власне координаційна робота УВО проходила в рамках УГК. «Офіційних нарад чи засідань ми не відбували, - відзначали члени Комітету. - Ми [О. Навроцький - $\boldsymbol{A m m}$.] обидва з Володимиром Целевичем працювали в одній кімнаті, Ярослав Чиж був близько, а Михайло Матчак і Юрко Полянський заходили до УГК часто. I не думали ми про якийсь регулямін, чи протоколи. Спочатку йшлося про те, щоб вишукувати старшин і стрільців та розбудовувати організацію» (Навроиький, 1963: 73). Надалі В. Целевич «від ранку до пізньої ночі» працював в УГК.

Незважаючи на застереження ПТК, УВО все частіше вдавалася до політичних акцій. Однією з перших акцій організації став бойкот рішення польського уряду про поділ Галичини на воєводства (ДАІФО, ф. 2, оn. 1, спр. 357, арк. 15). У жовтні 1920 р. члени Начальної команди, серед яких і В. Целевич, виготовили «проклямацію з протестом проти рішення польського уряду та розліпили iii по місті. «Обов'язок виконати цей задум упав на членів Начальної Колегіï, - зазначали учасники акції. - Кожний 3 нас дістав від Матчака згорток проклямацій, запасся в коробку з клеєм і квачем та ніччю вийшов на місто. Трохи було моторошно від незвичної роботи і все-таки небезпечного підприємства, бо ж могло статися таке, що при першій, на загал дрібній акщії, ледве створена Начальна Колегія УВО попадеться в польські руки. Та все пройшло щасливо...» (Навроцький, 1963: 74).

Зауважимо, що поступово роль В. Целевича в УВО, зважаючи на відсутність належного досвіду у військових кампаніях, звелася до суто організаційної роботи. Провід в організації перейняли Є. Коновалець, Д. Паліїв, Б. Гнатевич, В. Кучабський, О. Коберський, С. Федак та інші. військові, які «почували себе ще зв'язаними військовою дисципліною, а передусім братерством зброї, а дійсність під польським режімом ставала щораз більш болюча для тих, що ще так недавно були вояками вільної української 
держави і наявно бачили різницю між свободою у власній державі і поневоленням» (Навроцький, 1963: 75, 76).

Зрештою мілітаризація організації нерідко призводила до арештів iї провідних членів. Зокрема, 4 грудня 1919 р. підпоручник поліції Піхлер заарештував В. Целевича, М. Ільницького, I. Панчишина та Л. Малецького, яких помістили до в'язниці разом із рецидивістами. Тільки 9 грудня затриманих допитали і відпустили, зважаючи на відсутність складу злочину. Ув'язнення провідних членів УГУ та УВО викликало обурення широкої громадськості (ЦДІАЛ Украӥни, ф. 462, оп. 1, спр. 3, арк. 64).

Зокрема після наради Великої Ради, УГК надіслала лист до міністра внутрішніх справ Польщі Войціхівського, в якому вимагала звільнення ув'язнених та справедливого розслідування у справі (ЦДІАЛ України, ф. 462, on.1, спр. 3, арк. 64). У таких умовах В. Целевич усе більше схилявся до політичної діяльності, «культурно-освітньої й економічної праці для української людности своїх повітів». Більше того, О. Навроцький зазначає, що УВО на зламі 1921 - 1922 рр. делегувало В. Целевича, а також і його особисто «активізувати політичні партії»: першу - національнодемократичну, другу - радикальну.

«Не беруся твердити, що саме ми обидва зрушили їх, - продовжував О. Навроцький, - бо в одній і в другій партіях були в проводі визначні громадяни й політики, що відчували свою відповідальність і не потребували заохоти збоку, але все ж таки ми немало причинилися до того, що вони почали активніше виступати та що прийшло до створення Міжпартійної Ради 3 націоналдемократів, радикалів і християнських суспільників» (Навроцьький, 1963: 77).

Провідні члени УНДП доволі насторожено сприймали перебування В. Целевича в УВО. Проте більшість «цивільних» 3-поміж членів Міжпартійної Ради і Партійних проводів «багато чого здогадувалися, та не прозраджувалися з тим і не плескали язиками». Щоб уникнути зайвих конфліктів, О. Навроцький та В. Целевич «брали участь у засіданнях і нарадах Міжпартійної Ради не як представники Української Військової Організації, тільки як умандатовані члени представництва політичних партій, що до них кожен... належав. Всі годилися з фактом існування УВО і відносилися до здогадних членів Начальної Команди УВО 3 довір'ям і 3 прихильністю» (Навроцький, 1963: 77). 
Після замаху С. Федака на маршала Й. Пілсудського та воєводу В. Грабовського 25 вересня 1921 р. В. Целевич був арештований, оскільки він був втаємничений у деталі проведення операції. Тому, коли він разом із О. Навроцьким прийшли до батька С. Федака «в понеділок уранці, на другий день по атентаті, до його бюра в «Дністрі», а ми робили це кожного дня для обговорення біжучої роботи в Українськім Горожанськім Комітеті - то він стрінув нас такими словами: «Не маю до вас, хлопці, жалю, що ви призначили мого сина. Але кому прийшло до голови вибрати саме сина Федака, що, як Голова Українського Горожанського Комітету, репрезентує тепер українців?». Не ждучи на нашу відповідь, казав нам сідати і реферувати справи» (Навроиький, 1963: 78).

Уже 16 жовтня 1921 р. арештували В. Целевича та інших членів УГК, а 19 жовтня того ж року влада взагалі заборонила діяльність Комітету. Українська преса назвала цей день (16 жовтня) «Чорною неділею». Уже о восьмій годині ранку поліція провела обшук у приміщенні УГК, а також у будинку В. Целевича та О. Навроцького. Останніх згодом «спроваджено до Комітету, щоб вони були присутні при ревізіях, а відтак їх доведено до арешту» (Чорна неділя у Львові, 1921: 1). «Чорна неділя зробила велике вражіння на львівську людність, - відзначали кореспонденти «Свободи». - Цілий день люде стояли громадками на вулицях $\mathrm{i}$ дивилися, як транспорти арештованих під сильними ескортами відпроваджувалися до поліції. Не в одного українця стискались п'ястки і виривались 3 уст глухі прокльони - та не сила було щось зробити...» (Чорна неділя у Львові, 1921: 1).

Додамо, що В. Целевич був добре ознайомлений із особливостями проведення іншого, не менш резонансного агентату - замаху на угодовця С. Твердохліба. О. Навроцький зазначав, що на другий день після атентату на С. Твердохліба, С. Коновалець «зумисне зайшов, щоб поінформувати, що організатор атентату Дзіковський заломився, стратив нерви, готовий «засипати» всіх і вся. Сказав, що ввечері виїздить на село, до батьків, що Володимир Целевич уже перенісся до мешкання д-ра Степана Біляка і радив також подумати про те, щоб скритися на якийсь час» (Навроцький, 1963: 79).

Однак, не послухавши С. Коновальця, О. Навроцький потрапив у поліційний відділок, де «інсп. Лукомський та підкомісар Чеховський і навипередки один поперед другого питалися, чи знаю я полк. Свгена Коновальця та Володимира Целевича і де вони. 3 того 
я виміркував, що вони обидва не дали себе схопити. Стало мені легше на душі, і я спокійно відповів їм, що обидвох тих панів знаю, але невідомо мені, де вони тепер» (Навроцький, 1963: 79).

Незважаючи на репресії, В. Целевич не полишив (припинив) контактів із Є. Коновальцем та провідними членами УВО. Він був втаємничений у переговори Начальної колегії УВО із еміграційним урядом ЗУНР. Зокрема, одна із таких зустрічей відбулася восени 1922 року. О. Навроцький у спогадах відтворив деталі цієї події: «Зустріч з членами Делегатури [ЗУНР - $\mathbf{A m m}$.] відбулася в будинку «Сільського Господаря» при вул. Зіморовича, ч. 20, в кімнаті на першому поверсі. Не пригадую точно, хто з членів Делегатури, крім проф. Галущинського, був на цій зустрічі. Здається мені, що д-р Іван Куровець, д-р Володимир Охримович, інж. Юліян Павликовський і ще дехто. Нас було трьох - полк. Євген Коновалець, Володимир Целевич і я, правдоподібно також проф. Юрко Полянський. Зустріч тривала коротко. Проф. Галущинський з'ясував ситуацію і запитався Полковника, чи і як Українська Військова Організація задумує реагувати. Полковник заявив, що Начальна Команда УВО дасть наказ припинити саботажну акцію і заподав причини. На цьому зустріч закінчено і всі розійшлися» (Навроцький, 1963: 79).

Вагомим був внесок В. Целевича у підписання заяви Міжпартійної ради від 22 січня 1922 р., в якій йшлося про цілковиту довіру до уряду Є. Петрушевича. «Д-р Свген Петрушевич і його уряд являються єдиним правним заступництвом українського населення Східної Галичини, отже величезної більшости населення нашого краю взагалі, перед державами й народами світу». Цікаво, що серед 15 осіб прізвище В. Целевича у заяві на другому місці після голови УНТП. Часопис «Свобода» риторично запитував: «Який українець не знає цих імен наших давніх і випробуваних борців за народне право?» (Свобода, 1922: 1).

У цей ж період В. Целевич долучається до допомогової акції української еміграції. У 1923 - 1924 рр. він перебував у США та Канаді, де збирав кошти на культурно-освітні та соціальноекономічні потреби українства. В. Качкан справедливо зазначав, що «про його діяльність тут, на жаль, скупі дані» (Качкан, 2009: 159). Проте, у спогадах П. Задорецького знаходимо відомості, які свідчать про його активну громадсько-політичну й освідомлюючу працю на американському континенті: «Пригадую, як сьогодні, 
що це була субота, коли дістав я листа, читав і очам своїм не вірив, що «якийсь визначний гість з Свропи конче хоче зі мною бачитись». 3 великою цікавістю телефоную до п. Галичина і питаю, хто саме $є$ той визначний гість? Довго тієї ночі з суботи на неділю не міг я заснути. Перейшов у своїх думках усіх відомих мені в краю наших визначних людей і спинився на особі добре відомого мені особисто нашого судді Володимира Целевича, який після Першої світової війни бував у мене в хаті в Нью-Йорку, тож здавалось мені, що суддя Целевич висланий з краю в Америку 3 якоюсь важною справою. Він знав мене 3 часів січового руху в Америці, коли він, як суддя, переводив серед нью-йоркських січовиків «присягу на вірність і поміч українському народові в його визвольній боротьбі» та промовляв на січовім святі для відзначення «Листопадового Чину» (святкування дало почин до відзначення «Першого Листопада» по всіх українських громадах в Америці)» (Свген Коновалець та його доба, 1974: 826). Після повернення із американського континенту та виходу із УВО В. Целевич став одним із лідерів новоутвореного УНДО, що започаткувало новий етап у його політичній біографії.

Отже, перші кроки у громадсько-політичному житті краю В. Целевич здійснив у лавах УСС, націонал-демократичної секції цієї студентської організації, де гуртувалися студенти-прихильники Української Національно-Демократичної Партії (УНДП), а також УГК, який базував свою діяльність на позапартійній основі та опікувався національно-культурним та соціально-економічним життям українців Східної Галичини. У цей же період він став одним із засновників УВО, а після повернення із еміграції розпочав політичну кар'єру.

\section{Список використаних джерел та літератури}

ДАІФО, ф. 2, оп. 1, спр. 357.

Діло. 1913. 4 лютого. С. 1.

Євген Коновалець та його доба. Мюнхен, 1974. 1019 с.

Качкан В. Україноцентризм Володимира Целевича. Наукові записки Тернопільського національного педагогічного університету ім. Володимира Гнатюка. Серія «Літературознавство». Тернопіль, 2006. № 27. С. 139 - 154 . 
Книш 3. Підгрунтя УВО. Статmі й матеріали до діяння Украӥнської Військової Організаџії. Торонто: Срібна сурма, 1963. Ч. 2. С. $23-48$.

Навроцький О. Початки УВО в Галичині-II. Статті й матеріали до діяння Української Військової Організації. Торонто: Срібна сурма, 1963. Ч. 2. [Електронний ресурс]. - Режим доступу: http:// knysh.national.org.ua/uvo-2/r02.html (дата перегляду: 3 грудня 2018 p.)

Украинские националистические организации в годы второй мировой войны. документы. в двух томах. том 2. 1944 - 1945. Биографические справки. м., 2005. с. 1085.

ЦДІАЛ України, ф. 462, оп. 1, спр. 2.

ЦДІАЛ України, ф. 462, оп. 1, спр. 3.

Чорна неділя у Львові. Свобода. 1921. 5 листопада. С. 1.

\section{REFERENCES}

DAIFO, p. 2, op. 1, sp. 357. (ukr).

Business, 1913. February 4, p. 1. (ukr).

Eugene Konovalets and his day. Munich, 1974. 1019 p. (ukr).

Kachkan V., 2006. Ukrainian Centerism of Volodymyr Tselevich. Scientific notes of the Ternopil National Pedagogical University named after. Volodymyr Hnatyuk. Series "Literary Studies". Ternopil, No. 27. pp. 139 - 154. (ukr).

Knysh Z., 1963. Podvoroho UVO. Articles and materials for the action of the Ukrainian Military Organization. Toronto: Silver Antimony, 1963. Part 2, pp.23 - 48. (ukr).

Navrozky o., 1963. beginning of the uho in galicia-ii. articles and materials for the action of the ukrainian military organization. toronto: silver antimony, 1963. part 2. [electronic resource]. Available at: http://knysh.national. org.ua/uvo-2/r02.html [Accessed 3 December 2018] (ukr).

Ukrainian nationalist organizations during the Second World War. Documents In two volumes. Volume 2. 1944 - 1945. Biographical information. Moscow, 2005. p. 1085. (rus).

CDIAL Ukraine, f. 462, op. 1, sp. 2. (ukr).

CDIAL of Ukraine, f.462, op.1, sp.3. (ukr).

Black Sunday in Lviv, 1921. Freedom. 5 November, p. 1. (ukr). 


\section{Serediuk}

VOLODYMYR TSELEVYCH: CONTRIBUTION TO THE ESTABLISHMENT OF THE UKRAINIAN HOROZHANSKY COMMITTEE AND THE UKRAINIAN MILITARY ORGANIZATION

The social-political activity of the well-known Galician politician Volodymyr Tselevych during the first two decades of the twentieth century was analyzed in the light of socio-political processes in the region. It was noted that the future leader of the Ukrainian NationalDemocratic Association started his "political career" in the Division of the IV Section of the Ukrainian Student Union, as well as in the National-Democratic section of this student organization, where the students of the Ukrainian National Democratic Party were grouping together.

A particular focus was made on the peculiarities of the formation of his belief system, his contribution to the founding of the Ukrainian Horozhansky Committee, the Ukrainian Military; the circle of his fellow-thinkers was distinguished, among which were the future leaders of the national-state parties of Galicia and the national-cultural organizations of the region. It was proved that the role of $\mathrm{V}$. Tselevych in the Ukrainian Military Organization (UMO) due to the lack of proper experience in military campaigns was gradually reduced to a purely organizational work, and E. Konovalets, D. Paliyiv, V. Kuchabskyi, O. Koberskyi, S. Fedak, etc. took over the leadership in the organization.

The activities of Volodymyr Tselovych at the Ukrainian Horozhansky Committee (UHC) were considered; he directed his activities to meet the daily needs and protect the Ukrainians of Lviv. It was noted that as a secretary of the organization, he coordinated the activities of a number of committees and sections that provided material assistance to captives, arrested and feeble persons, was engaged in mediation regarding matters of employment, provided legal advice.

It was stated that Volodymyr Tselevych, while being in the UHC, UMO during the period of national liberation struggles, the PolishUkrainian war of 1918-1919, made significant efforts to protect the national-cultural, social and political rights of the Ukrainians of Eastern Galicia, collaborated with the Ukrainian political emigration, which caused him sufferings from repressions and persecutions from the Polish authorities.

Keywords: V. Tselevych, WUPR, UHC, UMO, repressions. 